\title{
FENOMENA KRIMINALITAS REMAJA DI KOTA DEPOK
}

\author{
Farah Januati dan Marjan Miharja \\ Sekolah Tinggi Ilmu Hukum IBLAM Jakarta, \\ Jalan Kramat Raya No. 25 Senen Jakarta Pusat \\ langitkalimasada@gmail.com \\ Naskah diterima : 01/05/2019, revisi : 15/06/2018, disetujui 17/06/2019
}

\begin{abstract}
ABSTRAK
Fenomena Kriminalitas Remaja sudah menjadi pembicaraan umum baik di lingkungan Masyarakat, Pemerintah maupun Penegak hukum, dimana banyak sekali remaja yang melakukan tindak kriminal baik dilakukan secara sendiri ataupun secara berkelompok. Hal ini memerlukan adanya perhatian khusus serta penanganan yang tepat terhadap perilaku remaja tersebut. Peran Kepolisian sebagai Penegak Hukum dan masyarakat sekitar sangatlah penting demi terciptanya harapan untuk membimbing para remaja agar dapat berperilaku baik di dalam berkehidupan bermasyarakat. Di dalam jurnal ini penulis mencoba membahas masalah tindak kriminalitas yang dilakukan oleh para remaja yang terjadi di kota depok, antara lain; apa yang menjadi faktor penyebab perilaku remaja tersebut, apa upaya yang harus dilakukan untuk mengatasi masalah tersebut, dan bagaimana aspek hukumnya. Dengan demikian diharapkan angka kriminalitas yang dilakukan oleh para remaja khususnya di kota Depok dapat diminimalisir.

Kata kunci : Remaja, kriminalitas, aspek hukum.
\end{abstract}

\section{Latar Belakang}

Akhir akhir ini sering terjadi tindak kriminalitas yang dilakukan oleh para remaja yang meresahkan masyarakat khususnya di daerah depok. Perilaku tersebutdilakukan secara berkelompok atau disebut dengan "geng" dimana mereka melakukan aksi tersebut tanpa merasa bersalah dan merupakan suatu kebangga an tersendiri. Mereka melakukan kekerasan seperti perampasan kendaraan bermotor yang sering disebut dengan aksi "begal” di jalan yang disertai aksi penganiayaan dan bahkan pembunuhan, 
pencurian seperti yang baru-baru ini terjadi di kawasan Depok dimana mereka menjarah sebuah toko baju dan para pelaku merupakan para remaja. Geng-geng ini terbentuk dari perkumpulan remaja-remaja yang memiliki sifat yang labil dan tidak terarah, yang pada awalnya berkumpul dengan mengendarai motor, kebut-kebutan di jalan dan karena kurangnya pengawasan dari lingkungan sekitar dan para orang tua akhirnya mereka melakukan perbuatan-perbuatan kriminal. Hal ini sangat meresahkan masyarakat.

Menurut Romli Atmasasmita perilaku kriminalitas yang dilakukan oleh remaja yang disebut dengan Juvenile delinquency adalah setiap perbuatan atau tingkah laku seeorang anak di bawah umur 18 tahun dan belum kawin yang merupakan pelanggaran terhadap norma-norma hukum yang berlaku serta dapat membahayakan perkembangan pribadi anak yang bersangkutan. ${ }^{1}$

Seperti yang kita ketahui masa remaja sering dikenal dengan istilah masa pemberontakan. Pada masa masa ini, seorang anak yang baru mengalami pubertas seringkali menampilkan beragam gejolak emosi, menarik diri dari keluarga, serta mengalami banyak masalah, baik di rumah, sekolah atau lingkungan pertemanannya. Faktor pemicunya, menurut sosiolog Kartono, antara lain adalah gagalnya remaja melewati masa transisinya, dari anak kecil menjadi dewasa, dan juga karena lemahnya pertahanan diri terhadap pengaruh dunia luar yang kurang baik. ${ }^{2}$

Menurut Santrock kenakalan remaja sendiri mengacu kepada rentang perilaku yang luas mulai dari perilaku yang tidak dapat diterima secara sosial seperti tindakan berlebihan di sekolah, pelanggaran-pelanggaran seperti melarikan diri dari rumah sampai pada perilaku-perilaku kriminal. ${ }^{3}$

\footnotetext{
${ }^{1}$ Romli Atmasasmita, Problem Kenakalan Anak-Anak Remaja, (Bandung:Armico,1983)hlm.40

2 Kartini Kartono, Patologi Sosial 2 Kenakalan Remaja, Jakarta : Rajawali Pers, 2014.

3 https:/www.google.co.id/amp/s/psikologoforensik.com/2015/01/30/ada-apa-di-balik-kriminalitasremaja-indonesia/amp/
} 
Menurut Soerjono Soekanto "delinkuensi anak-anak yang terkenal di Indonesia adalah masalah cross boys dan cross girls yang merupakan sebutan bagi anak-anak muda yang tergabung dalam suatu ikatan/organisasi formal maupun semi formalyang mempunyai tingkah laku yang kurang/tidak disukai oleh masyarakat pada umumnya. Delikuensi anak anak di Indonesia meningkat pada tahun-tahun 1956 dan 1958 dan juga pada 1968-1969, hal mana sering disinyalir dalam pernyataan -pernyataan resmi pejabat maupun petugas penegak hukum.

Delikuensi anak-anak meliputi pencurian, perampokan, penganiayaan, pelanggaran susila, penggunaan obat obat terlarang dan lain sebagainya. ${ }^{4}$ Dari penjelasan di atas maka dapat disimpulkan bahwa kenakalan remaja tidak hanya meliputi tindakan-tindakan kriminal saja, melainkan segala tindakan yang dilakukan oleh remaja yang dianggap melanggar nilai nilai sosial, di sekolah maupun masyarakat.

Salah satu faktor yang diyakini oleh masyarakat untuk dapat membendung dan mengurangi resiko negatif dari perkembangan pada masa remaja adalah dengan memberikan pendidikan agama dan menanamkan nilai-nilai agama pada anak sejak kecil, dalam keluarga, di sekolah dan dalam lingkungan masyarakat. Semakin banyak pengalaman yang bersifat agama, (sesuai agama yang dianut) maka sikap, tindakan, kelakuan dan caranya menghadapi hidup akan sesuai dengan ajaran agama. Di samping pemahaman terhadap ajaran agama, peran orang tua dalam mendidik dan mengasuh anak-anak pun harus mengerti dasar dasar pendidikan. Menurut Zakiah Daradjat apabila pendidikan dan perlakuan yang diterima oleh sang anak sejak kecil merupakan sebab -sebab pokok dari kenakalan anak-anak, maka setiap orang tua haruslah mengetahui dasar-dasar pendidikan, minimal tentang jiwa si anak dan Pers, 2015.

${ }^{4}$ Soerjono Soekanto, Sosiologi Suatu Pengantar, Cetakan ke 44 hal. 328-329 Jakarta : Rajawali 
pokok pokok pendidikan yang harus dilakukan dalam menghadapi bermacam macam sifat si anak. Selain itu peranan masyarakat dan penegak hukum sangat dibutuhkan. ${ }^{5}$

\section{Pembahasan}

1. Pengertian Remaja / anak yang belum dewasa

Menurut para ahli :

a. Menurut Zakiah Daradjat, masa remaja (adolensi) adalah "masa peralihan dari masa- anak-anak menuju masa dewasa, dimana anak-anak mengalami pertumbuhan cepat di segala bidang. Mereka bukan lagi anak-anak baik bentuk jasmani, sikap, cara berfikir dan bertindak, tetapi bukan pula orang dewasa yang telah matang. Masa ini dimulai kira-kira pada umur 13 tahun dan berakhir kira-kira umur 21 tahun. ${ }^{6}$

b. Menurut Hurlock, Remaja berasal dari kata latin adolescence yang bearti tumbuh atau tumbuh menjadi dewasa. Istilah adolescence mempunyai arti yang lebih luas lagi yang mencakup kematangan mental, emosional sosial dan fisik. ${ }^{7}$

c. Menurut Santrock, bahwa adolescence diartikan sebagai masa perkembangan transisi antara masa anak dan masa dewasa yang mencakup perubahan biologis, kognitif dan sosial emosional. ${ }^{8}$

Menurutaturan Hukum di Indonesia :

a. Pasal 1 angka (1) Undang-undang Nomor 3 Tahun 1997 tentang Pengadilan Anak menyatakan bahwa anak adalah orang yang dalam perkara anak telah mencapai umur 8 (delapan) tahun tetapi belum mencapai 18 tahun dan belum kawin. Ketentuan pasal ini mendapat

\footnotetext{
${ }^{5}$ Zakiah Daradjat, Kesehatan Mental, cetakan ke-5 Jakarta : Gunung Agung, 2016.

${ }^{6}$ Zakiah Daradjat, Kesehatan Mental, cetakan ke-5 Jakarta : Gunung Agung, 2016

${ }^{7} \mathrm{http}: / /$ www.dosenpendidikan.com/7-pengertian-remaja-menurut-para-ahli-secara-lengkap/ diakses pada tanggal 17 Januari 2018

${ }^{8} \mathrm{http}: / /$ belajarpsikologi.com/pengertian-remaja/diakses pada tanggal 17 januari 2018
} 
pengecualian apabila seseorang yang belum mencapai 18 (delapan belas) tahun tetapi telah melakukan perkawinan/pernikahan, maka anak tersebut tetap dianggap telah dewasa walaupun umurnya belum mencapai 18 tahun. $^{9}$

b. Menurut UU Peradilan Pidana Anak No 3 Tahun 2012 Pasal 1 angka 3 Remaja adalah individu yang berusia 12 (dua belas) tahun, tetapi belum berumur 18 (delapan belas) tahun yang diduga melakukan tindak pidana. ${ }^{10}$

Tindak kriminal yang dilakukan oleh remaja adalah suatu tindakan kriminal yang melanggar norma-norma kehidupan yang dapat menimbulkan keresahan,kerugian baik materil maupun spiritual,serta mengancam jiwa manusia. Perilaku tersebut berupa : pencurian, perampasan barang dengan aksi kekerasan.

2. Faktor Penyebab terjadinya tindakan kriminalitas oleh remaja. ${ }^{11}$

a. Kurangnya peran orang tua

Peran orang tua dalam mendidik anak sejak dini sangatmempengaruhi perilaku anak ketika dewasa, didikan yang baik di dalam lingkungan keluarga serta memberikan pemahaman tentang norma-norma, menjadikan seorang anak mampu untuk memilah mana hal yang baik untuk dilakukan , dan mana yang tidak baik untuk dilakukan.

\footnotetext{
${ }^{9}$ Undang-Undang No 3 Tahun 1997 Tentang Pengadilan Anak, Lembaran Negara Republik Indonesia Nomor 3 Tahun 1997

${ }^{10}$ Undang-Undang No 11 tahun 2012 tentang Sistem Peradilan Pidana Anak, Lembaran Negara Republik Indonesia Tahun 2012 Nomor 153

$11 \mathrm{http}: / /$ wawasanpendidikan.com/2015/02/upaya-penanggulanan-kenakalan-remaja.html diakses pada tanggal 17 Januari 2018
} 
b. Dunia pergaulan yang rusak.

Biasanya berawal dari mereka yang berteman dengan teman yang membawa dampak buruk, karena masa remaja itu adalah keadaan dimana keadaan psikis remaja bisa mudah terpengaruh.

c. Kurangnya pemahaman agama.

Pemahaman tentang agama diyakini dapat membentengi pikiran dan jiwa anak. Oleh karena itu pendidikan dasar agama pada anak sangat diperlukan dalam kehidupan remaja.

d. Peran dari perkembangan IPTEK yang membawa dampak negatif. Perkembangan iptek di era sekarang dapat mempengaruhi perilaku remaja dimana anak mudah mengakses informasi tanpa batas sehingga mereka meniru, yang akhirnya membawa mereka melakukan tindakan-tindakan yang melanggar norma-norma kehidupan, seperti : pengunaan narkoba, seks bebas, mengkonsumsi minuman keras, keinginan untuk memiliki suatu barang atau ingin terlihat lebih dari temannya, sehingga mereka rela melakukan tindakan-tindakan kriminal untuk mewujudkan keinginan mereka yang semata-mata hanya untuk memperoleh kesenangan pribadi.

e. Kebebasan yang berlebihan

Kebebasan yang didapati anak tanpa pengawasan baik dari keluarga maupun lingkungan masyarakat merupakan hal yang memicu remaja untuk melakukan hal-hal yang tidak baik.

f. Krisis identitas

Perubahan biologis dan sosiologis pada diri remaja memungkinkan terjadinya dua bentuk integrasi. Pertama, terbentuknya perasaan akan konsistensi dalam kehidupannya. Kedua, tercapainya identitas peran. Kenakalan remaja terjadi karena remaja gagal mencapai masa integrasi kedua. 
g. Kontrol diri yang lemah

Remaja yang tidak bisa mempelajari dan membedakan tingkah laku yang dapat diterima dengan baik dengan yang tidak dapat diterima akan terseret pada perilaku 'nakal'. Begitupun bagi mereka yang mengetahui perbedaan dua tingkah laku tersebut, namun tidak bisa mengembangkan kontrol diri untuk bertingkah laku sesuai dengan pengetahuannya.

h. Komunitas/ lingkungan tempat tinggal yang tidak baik. ${ }^{12}$

i. Upaya penanggulangan Kriminalitas Remaja.

A. Secara preventif dan Kuratif

Menurut Soewarno Soerjo Poetro ada dua unsur terjadinya pelanggaran yaitu niat untuk melakukan suatu pelanggaran dan kesempatan untuk melakukan niat tersebut. Jika hanya salah satu unsur saja maka belum terjadi pelanggaran, Widayanti dan Waskita. Tindak kekerasan yang dilakukan remaja banyak menimbulkan kerugian materiil dan kesengsaraan batin baik pada subyek pelaku sendiri pada korbannya, maka masyarakat dan pemerintah melakukan tindakan preventif dan penaggulangan secara kuratif. ${ }^{13}$

a. Tindakan preventif yang dapat dilakukan berupa :

1) Meningkatkan kesejahteraan keluarga

2) Perbaikan lingkungan yaitu daerah slum, kampung-kampung miskin

3) Mendirikan klinik bimbingan psikologis dan edukatif untuk memperbaiki tingkah laku dan membantu remaja dari kesulitan mereka

\footnotetext{
12 Ibid.

${ }^{13}$ Ibid.
} 
4) Menyediakan tempat rekreasi yang sehat bagi remaja

5) Membentuk badan kesejahteraan anak-anak

6) Mengadakan panti asuhan

7) Mengadakan Pengadilan anak

8) Mengadakan rumah tahanan khusus untu anak dan remaja

b. Tindakan kuratif bagi usaha penyembuhan anak nakal, antara lain :

1) Menghilangkan semua sebab musabab timbulnya kejahatan remaja baik yang berpa pribadi, familial, sosial ,ekonomi dan kultural.

2) Melakukan perubahan lingkungan dengan jalan mencarikan orang tua angkat.

3) Memindahkan anak-anak nakal ke sekolah yang baik

4) Memberikan latihan bagi para remaja untuk hidup teratur, tertib dan berdisiplin.

5) Menggiat organisasi pemuda dengan program-program latihan vokasional untuk mempersiapkan anak remaja yang nakal itu bagi pasaran kerja dan hidup ditengah masyarakat.

6) Memperbanyak bimbingan latihan kerja dengan program kegiatan pembangunan 14

Kedua metode tersebut secara konsisten memiliki peran yang sangat penting dalam menanggulangi kenakalan remaja, sehingga anak yang nakal ini dapat kembali normal sebagaimana anak pada umumnya.

B. Upaya pencegahan kenakalan Remaja yang Bersifat Khusus dan Langsung15

a. Pengawasan 
1) Dengan kerjasama antara polisi dengan pimpinan sekolah dan para guru, perlu diadakan penertiban terhadap para murid dengan sasaran sebagai berikut:

a) Apakah cara berpakaian dan menghias diri murid-murid sekolah tertib atau tidak

b) Apakah terdapat benda-benda terlarang yang dibawa atau dipunyai oleh murid-murid sekolah itu

c) Apakah terdapat tanda-tanda permusuhan diantara kelompok murid-murid sekolah itu

2) Patroli dan penertiban tersebut di atas hendaknya dilakukan tidak pada jam-jam pelajaran

3) Membentuk badan keamanan sekolah yang dilakukan oleh siswa siswi sendiri dengan bimbingan dari polisi dan kepala sekolah.

4) Patroli tempat rekreasi oleh polisi untuk memeriksa dan mencegah kemungkinan adanya remaja yang memasuki tempattempat terlarang atau berbuat hal-hak tercela.

5) Pengawasan tempat-tempat hiburan oleh polisi atau pembantu keamanan yang ditugaskan oleh polisi untuk mencegah dan memeriksa remaja yang memasuki tempat hiburan tersebut padahal tidak diperuntukkan bagi golongan mereka.

6) Pengawasan tempat-tempat judi, rumah-rumah minum tempat pelacuran untuk memeriksa dan mencegah adanya remaja yang memasuki ruangan atau daerah yang terlarang untuknya.

7) Pengawasan penertiban, penyitaan dan pemverantasan bacaanbacaan cabul, film-film cabul,gambar cabul, rekaman-rekaman cabul dengan maksud agar tidak terbaca, terlihat ataupun terdengar oleh remaja. 
8) Pengawasan, penertiban, penyitaan dan pemberantasan obatobat terlarang yang beredar.

9) Pendaftaran dan pengawasan kegiatan-kegiatan perkumpulan organisasi dan gerakan remaja. ${ }^{16}$

b. Bimbingan dan Penyuluhan

Bimbingan dan penyuluhan secara intensif terhadap orang tua dan para remaja agar orang tua dapat membimbing dan mendidik anakanaknya secara sungguh-sungguhdan tepat agar para remaja tetap bertingkah laku yang wajar.

c. Pendekatan-pedekatan khusus

Pendekatan-pendekatan khusus terhadap remaja yang sudah menunjukkan gejala-gejala kenakalan perlu dilakukan sedini mungkin. Sedangkan tindakan represif terhadap remaja nakal perlu dilakukan pada saat-saat tertentu oleh instansi kepolisian RI bersama badan peradilan yang ada. Tindakan ini harus dijiwai dengan rasa kasih sayang yang bersifat mendidik terhadap mereka. Oleh karena itu perilaku nakal yang mereka perbuat adalah akibat produk dari berbagai faktor intern dan ekstern remaja yang tidak disadari dapat merugikan pribadinya sendiri dan masyarakatnya.

C. Upaya Rehabilitasi Remaja

a. Bidang mental dan spiritual

Bidang agama lebih serius dan intensif serta perlu diberi pengertian tentang hukum dan ketentuan agama yang akan menjamin keamanan dan ketentraman batinnya.

b. Bidang Fisik

${ }^{16} \mathrm{Ibid}$. 
Bidang fisik, misalnya perlu diberi latihan olah raga yang menunjang kesehatan fisik mereka.

c. Bidang sosial

Kenakalan remaja kadang-kadang disebabkan oleh lingkungan sosial yang jauh dari agama, dimana nilai yang dianut oleh lingkungan masyarakat mungkin bertentangan dengan nilai-nilai yang terdapat dalam agama sehingga dengan mudah para remaja melakukan hal terlarang, oleh karena itu perlu dihidupkan suasana keagamaan didalam masyarakat maupun keluarga.

d. Sarana-sarana rehabilitasi

Dengan didirikannya biro-biro konsultasi baik di sekolah maupun ditiap-tiap RT atau RW yang sebaiknya bertempat di masjid atau langgar guna mendekatkan anak kepada Tuhan, disamping menolongnya mengatasi problem hidup. ${ }^{17}$

Semua usaha penanggulangan tersebut hendaknya didasarkan atas sikap dan pandangan bahwa remaja adalah hamba Allah yang masih dalam proses perkembangan/pertumbuhan menuju kematangan pribadinya yang membutuhkan bimbingan dari orang dewasa yang bertanggung jawab.

j. Aspek hukum kriminalitas remaja.

Tindakan kriminal merupakan sebuah tindakan yang mengakibatkan hukum, Menurut Undang-Undang Nomor 3 Tahun 1997 tentang Peradilan Anak terhadap anak nakal dapat dijatuhkan pidana yaitu pidana pokok dan pidana tambahan atau tindakan. Dengan menyimak Pasal 23 ayat (1) dan ayat (2) diatur pidana pokok dan pidana tambahan bagi anak nakal. ${ }^{18}$

1. Pidana Pokok

\footnotetext{
17 Ibid.

$18 \mathrm{http} / / /$ pendidikan-hukum.blogspot.co.id/2010/10/pelanggaran-pidana-anak-anak-dala m.ht $\mathrm{ml}$ ? $\mathrm{m}=1$
} 
Ada beberapa pidana pokok yang dapat dijatuhkan kepada anak nakal, yaitu:
a. Pidana penjara
b. Pidana kurungan
c. Pidana denda, atau
d. Pidana pengawasan

2. Pidana Tambahan

Pidana tambahan terdiri dari :
a. Perampasan barang-barang tertentu
b. Pembayaran ganti rugi

3. Tindakan

Beberapa tindakan yang dapat dijatuhkan kepada anak nakal (Pasal 24 ayat

(1) Undang-Undang Npmor 3 Tahun 1997) adalah : 19

a. Mengembalikan kepada orang tua, wali, atau orang tua asuh

b. Menyerahkan kepada Negara untuk mengikuti pendidikan, pembinaan, dan latihan kerja,

c. Menyerahkan kepada Departemen Sosial, atau organisasi sosial kemasyarakatan yang bergerak dibidang pendidikan,pembinaan dan latihan kerja.

Selain tindakan tersebut, hakim dapat memberi teguran dan menetapkan syarat tembahan. Penjatuhan tindakan oleh hakim dilakukan kepada anak yang melakukan perbuatan yang dinyatakan terlarang bagi anak,baik menurut peraturan perundang-undangan maupun menurut peraturan hukum lain.

Dalam segi usia, pengenaan tindakan terutama bagi anak yang masih berumur 8 (delapan) tahun sampai 12 (dua belas) tahun. Terhadap anak yang telah melampaui umur diatas 12 (dua belas) tahun dijatuhkan hukuman pidana.

${ }^{19}$ Bambang Waluyo, Pidana dan Pemidanaan,(Jakarta : Sinar Grafika, 2004) hlm 27 
Hal itu mengingat pertumbuhan dan perkembangan fisik, mental, dan sosial anak. Menurut Pasal 132 rancangan KUHP adalah :

1. Pengembalian kepada orang tua, wali, atau pengasuhnya

2. Penyerahan kepada pemerintah atau seseorang

3. Keharusan mengikuti suatu latihan yang diadakan oleh pemerintah atau suatu badan swasta,

4. Pencabutan izin mengemudi

5. Perampasan keuntungan yang diperoleh dari tindak pidana

6. Perbaikan akibat tindak pidana

7. Rehabilitasi, dan atau

8. Perawatan dalam suatu lembaga

4. Pidana Penjara

Berbeda dengan orang Dewasa, pidana penjara bagi anak nakal lamanya $1 / 2$ (satu perdua) dari ancama pidana orang dewasa atau paling lama 10 (sepuluh) tahun. Terhadap anak nakal tidak dapat dijatuhkan pidana mati maupun pidana seumur hidup. Dan sebagai gantinya adalah dijatuhkan salah satu tindakan. ${ }^{20}$

5. Pidana Kurungan

Pidana kurungan yang dapat dijatuhkan kepada anak nakal maksimal setengah dari maksimum ancaman pidana kurungan bagi orang dewasa. Mengenai apakah yang dimaksud maksimum ancaman pidana kurungan bagi orang dewasa, adalah maksimum ancaman pidanan kurungan terhadap tindak pidana yang dilakukan sesuai dengan yang ditentukan dalam KUHP atau Undang-undang lainnya (penjelasan pasal 27)21

6. Pidana Denda

20 Ibid., hlm. 29.

${ }^{21}$ Ibid. 
Seperti pidana penjara dan pidana kurungan maka penjatuhan pidana denda juga dijatuhkan setengah dari maksimum ancaman pidana denda bagi orang dewasa. Bila denda itu tidak dapat dibayar, maka wajib diganti dengan latihan kerja selama 90 hari dengan jam kerja tidak lebih dari 4 jam sehari dan tidak boleh dilakukan dimalam hari. Tentunya hal demikian mengingat pertumbuhan dan perkembangan fisik, mental dan sosial anak serta perlindungan anak. ${ }^{22}$

7. Pidana Bersyarat

Garis besar ketentuan pidana bersyarat bagi anak nakal sesuai dengan rumusan Pasal 29 Undang-Undang Nomor 3 Tahun 1997 adalah :23

1. Pidana bersyarat dapat dijatuhkan, apabila pidana penjara dijatuhkan paling lama 2 (dua) tahun, sedangkan jangka waktu masa pidana bersyarat adalah paling lama 3(tiga) tahun.

2. Dalam putusan pidana bersyarat diberlakukan ketentuan berikut :

a. Syarat umum, yaitu anak nakal tersebut tidak akan melakukan tindak pidana lagi selama menjalani masa pidana bersyarat.

b. Syarat khusus, yaitu untuk melakukan atau tidak melakukan hal tertentu yang ditetapkan dalam putusan hakim dengan teteap memperhatikan kebebasan anak.

3. Pengawasan dan bimbingan

a. Selama menjalanimasa pidana bersyarat, jaksa melakukan pengawasan dan bimbingan kemasyarakatan melakukan bimbingan agar anak nakal menepati persyaratan yang telah ditentukan.

b. Anak nakal yang menjalani pidana bersyarat, dibimbing oleh balai pemasyarakatan berstatus klien pemasyarakatan.

\footnotetext{
22 Ibid., hlm. 30.

${ }^{23}$ UU Nomor 3 Tahun 1997 tentang Pengadilan Anak.
} 
c. Selama anak nakal berstatus sebagai klien pemasyarakatan dapat mengikuti pendidikan sekolah.

8. Pidana Pengawasan

Pidana pengawasan adalah pidana khusus yang dikenakan untuk anak yakni pengawasanyang dilakukan oleh jaksa penuntut umum terhadap perilaku anak dalam kehidupan sehari-hari dirumah, anak tersebut dalam pemberian bimbingan yang dilakukan oleh pembimbing kemasyarakatan. Anak nakal yang diputus oleh hakim untuk diserahkan kepada Negara ditempatkan di lembaga pemasyarakatan anak sebagai anak Negara, dengan maksud untuk menyelamatkan masa depan anak atau bila anak menghendaki, anak dapat diserahkan kepada orang tua asuh yang memenuhu syarat. 24

9. Restorative Justice.

Restorative justice adalah penyelesaian hukum terhadap anak di luar pengadilan. Dalam Pasal 1 UU SPA menegaskan sbagai berikut : ${ }^{25}$

“ Keadilan restoratif adalah penyelesaian tindak pidana dengan melibatkan pelaku/korban, dan pihak lain yang terkait untuk bersama-sama mencari penyelesaian yang adil dengan menekankan pemulihan kembali pada keadaan semula, dan bukan pembalasan."

Namun pada penerapannya di Indonesia restorative justice mengalami banyak hambatan diantaranya adalah :

a. An identifiable victim:

b. Voluntary participation by the victim;

c. On offender who accepts responsibility for his/her criminal behavior, and,

d. Non-coerced participation of the offender

${ }^{24}$ Bambang Waluyo, Pidana dan Pemidanaan, (Jakarta : Sinar Grafika, 2004, hlm 31

$25 \mathrm{https}$ ://s lis sety.wordpress.com/tindak-pidana-anak/ diakses tanggal 12 Februari 2018 
Hambatan lain menurut Thomas Raffles dalam bukunya berjudul History of java adalah bahwa orang jawa (maksudnya Indonesia) itu pendendam dan oleh karena itu sulit untuk diajak bermusyawarah untuk mencapai mufakat dan sulit untuk berkompromi. Masyarakat Indonesia menghendaki agar semua orang yang melakukan kejahatan agar masuk penjara agar ada efek jera. ${ }^{26}$

\section{Kesimpulan}

Fenomena kriminalitas yang dilakukan oleh para remaja yang merupakan suatu bentuk kenakalan remaja / juvenile delinquency merupakan hal yang melanggar norma, aturan atau hukum dalam masyarakat yang dilakukan pada usia remaja atau transisi masa anak-anak dan dewasa hal ini sangat meresahkan masyarakat. Faktor penyebabnya bisa berasal dari diri remaja itu sendiri, keluarga maupun lingkungan. Perilaku kriminal otomatis membawa mereka ke ranah hukum sesuai dengan aturan hukum yang berlaku di Indonesia. Peraturan yang mengatur remaja/anak yang melakukan tindak pidana tercantum dalam Undang-undang Nomor 3 Tahun 1997 tentang Pengadilan anak dan yang terbaru adalah Undang-Undang Nomor 11 Tahun 2012 tentang Sistem Peradilan Pidana anak yang mulai berlaku sejak 31 Juli 2014.

Namun dalam mengadili remaja/anak dibawah umur yang melakukan tindakan kriminal sampai saat ini masih mengalami pro dan kontra, aturan hukum yang dibuat oleh Negara untuk peradilan pidana anak yang harus memperhatikan Undang-Undang Perlindungan anak (UU No 23 th 2002) dan Hak asasi manusia (UU No. 39 Tahun 1999), membuat hukuman yang diterima oleh pelaku tindak kriminal (remaja/anak) sangatlah minimal yang kadang tidak memberikan efek jera.

${ }^{26} \mathrm{http}: / /$ www.bphn.go.id/data/documents/laporan_akhir_pengkajian_restorative_justice_anak.pdf diakses pada tanggal 12 Februari 2017 


\section{DAFTAR PUSTAKA}

Soekanto, Soerjono. Cetakan ke-44 2015. Sosiologi Suatu Pengantar, Jakarta : Rajawali Pers.

Kartono, Kartini Patologi Sosial 2 Kenakalan Remaja, Jilid 2 Jakarta: Rajawali Pers, 2014.

Daradjat,Zakiah Kesehatan Mental, cetakan ke-5 Jakarta : PT. Gita Karya, 2016

Romli Atmasasmita, Problem Kenakalan Anak-Anak Remaja, (Bandung:Armico,1983)

Bambang Waluyo, Pidana dan Pemidanaan, (Jakarta : Sinar Grafika, 2004)

http://belajarpsikologi.com/pengertian-remaja/

https://www.google.co.id/amp/s/psikologoforensik.com/2015/01/30/ada-apa-dibalik-kriminalitas-remaja-indonesia/amp/

http://www.wawasanpendidikan.com/2015/02/upaya-penaggulangan-kenakalanremaja.html

http://pendidikan-hukum.blogspot.co.id/2010/10/pelanggaran-pidana-anak-anakdalam.html?m=1

http://www.bphn.go.id/data/documents/laporan_akhir_pengkajian_restorative_justi ce_anak.pdf

Undang-Undang No 3 Tahun 1997 Tentang Pengadilan Anak, Lembaran Negara Republik Indonesia Nomor 3 Tahun 1997

Undang-Undang No 11 tahun 2012 tentang Sistem Peradilan Pidana Anak, Lembaran Negara Republik Indonesia Tahun 2012 Nomor 153 